\title{
An Essential Histidine Residue in the Catalytic Mechanism of the Rat Kidney $\gamma$-Glutamyl Transpeptidase
}

\author{
Soo-Ja Kim, ${ }^{\dagger}$ Moon Kyu Ko, ${ }^{\ddagger}$ Kyu-Yun Chai, ${ }^{\S}$ Seong-Wan Cho, and Woo-Yiel Lee ${ }^{\circ}$ \\ ${ }^{\dagger}$ Department of Chemistry, College of Liberal Arts and Sciences, Kunng-Hee Lniversity, Seoul 130-701, Korea \\ ${ }^{\ddagger}$ Department of Biochemical Engineering, Konvang Liniversity, Konsan 320-711, Korea \\ separtment of Namobiochemistry, Wonkwang Unimersitw, Iksan, Chonbuk 570-749, Korea \\ Department of Pharmaceutical Engineering, Konvang Linversity, Konsan 320-711, Korea. "E-mail: Lee0519akonyang.ackr \\ Received October 23, 2006
}

\begin{abstract}
$\gamma$-Glutamyl transpeptidase (EC 2.3.2.2) plays a key role in glutathione metabolism by catalyzing the transfer of the $\gamma$-glutamyl residue and hydrolysis of glutathione. The functional residues at the active site of the rat kidney $\gamma$-glutamyl transpeptidase were investigated by kinetic studies at various $\mathrm{pH}$. the treatment of diethy lpy rocarbonate (DEPC). and photooxidation in presence of methylene blue. An ionizable group affecting the enzy'matic activity with an apparent $\mathrm{pKa}$ value of 7.1. which is in the range of $\mathrm{pKa}$ values for a histidine residue in protein was obtained by examining the $\mathrm{pH}$-dependence of kinetic parameters. The $\mathrm{pH}$ effect on the photoinduced inactivation rate of the enzyme corresponds to that expected for the photooxidation of the free histidine. The involvement of a histidine in the catalytic site of the enzy'me was further supported by DEPC modification accompanied by an increase in absorbance at $240 \mathrm{~nm}$. indicating the formation of $\mathrm{N}$ carbethoxyhistidine. The histidine located at the position of 382 in the precursor of the enzyme is primarily suspected based on the amino acid sequence alignment of the transpeptidases from various organisms.
\end{abstract}

Key Words : Ganmin-glutamyl transpeptidase, Essential histidine, Kinetic study. Chemical modification, Photooxidation

\section{Introduction}

$\gamma$-Glutamyl transpeptidase $(\gamma-\mathrm{GT})$ that has been found in various mammalian tissues plays a key role in glutathione metabolism. ${ }^{1-3}$ The enzyme has been widely used as a tumor marker in experimental liver carcinogenesis and human cancer. It has been reported that significant changes in the elevated expression of the transpeptidase take place in liver and kidney during oncogenesis. ${ }^{4.5}$ Three molecular forms of human $\gamma$-GT have been found in normal and renal cell carcinoma tissues. ${ }^{5}$ Recent experiments have suggested that the transpeptidases undergo significant post-translational modification via proteolytic digestion and glycosylation. which may be different between normal and cancerous tissues. ${ }^{6.7}$ While the regulation of $\gamma$-GT and its relation to neoplasia is an area of current active research. information regarding its structural and catalytic aspects is little known in spite of the requirement in understanding its physiological function.

The highest activity of $\gamma$-GT has been found in the kidney of mammalian tissues. ${ }^{8}$ The rat kidney enż'me is an amphipathic heterodimer consisting of two glycosylated subunits. The heavy subunit ( $\mathrm{H} .51 \mathrm{kDa}$ ) contains a membrane spanning N-terminal segment. The light subunit (L. $22 \mathrm{kDa}$ ) noncovalently associated with the $\mathrm{H}$ subunit has been suggested to contain the active site residues. ${ }^{9-11}$ Previous immunological and kinetic experiments have suggested that the two subunits of rat kidney transpeptidase are synthesized as a single common polypeptide precursor $(78 \mathrm{kDa}){ }^{12}$ The rat transpeptidase gene has been cloned and well characterized as an attempt to elucidate the mechanism involving its tissue-specific transcription as well as its relation to neoplasia. ${ }^{13}$ Also the active site of rat kidney $\gamma$-GT was recently investigated using the various ester and amide derivatives of the well-known substrate $\mathrm{L}$ - $\gamma$-glutanyl- $p$-nitroanilide. ${ }^{1+}$ However. much less is known about the structural information in the catalytic site of the enz'me.

In the present work. kinetic studies. photooxidation, and chemical modification by diethylpyrocarbonate (DEPC) have been carried out in order to obtain information regarding functional amino acid residues at the catalytic site of rat kidney $\gamma$-GT. The results provide biophysical and chemical evidences that a histidine residue is involved in the active site of the enzyme.

\section{Materials and Methods}

Materials. $\gamma$-GT was isolated from rat kidney using Triton $\mathrm{X}-100$ detergent and converted to a water soluble form by papain treatment as previously described. ${ }^{15}$ The specific activity of the apparently homogeneous preparation as judged by native polyacrylamide gel electrophoresis was 393.70 units per $\mathrm{mg}$ when assayed as described below. The difference between this preparation and the previous one ( 488 units $/ \mathrm{mg}$ ) may be due to the different kidney donors. $\mathrm{L}-\gamma-$ glutamyl-p-nitroanilide ( $\gamma$-Glu-PNA), glycylglycine (GlyGly) and DEPC were purchased from Signa Chemical Co. (St. Louis. MO). Methylene blue was obtained from Wako Pure Chemicals (Japan). All other chemicals were of the highest purity commercially available. Cary model 17 spectro- 
photometer was used for kinetic studies and spectral experiments.

Enzymatic assay. $\gamma$-GT was assayed spectrophotometically using v-Glu-PNA according to the procedure described by Tate and Meister. ${ }^{16}$ The reaction mixture for a standard assay contained $2.5 \mathrm{mM} \gamma$-Glu-PNA, $20 \mathrm{mM}$ Gly -Gly, and $50 \mathrm{mM}$ Tris- $\mathrm{HCl}(\mathrm{pH} 8.0)$. One unit of transpeptidase is defined as the amount of enzyme that catalyzes release of $1 \mathrm{mmol}$ of $p$ nitroaniline per minute. Protein concentrations were determined by the method of Lowry et al. using bovine serum albumin as a standard protein. ${ }^{17}$

$\mathrm{pH}$ effect on the transpeptidase activity. The $\mathrm{pH}$ effect on the activity of rat kidney $\gamma$-GT was examined by measuring the rate of the $p$-nitroaniline production under the standard condition after incubation for 6 mins at various $\mathrm{pH}$ in the $\mathrm{pH}$ range of 4.0 to 11.0 . The following buffers were utilized at $50 \mathrm{mM}$ concentration for the $\mathrm{pH}$ ranges indicated: acetate. $\mathrm{pH}$ 4.0-5.5: phosphate. $\mathrm{pH}$ 6.0-6.8: Tris. $\mathrm{pH}$ 7.0-9.0: carbonate $\mathrm{pH} 9.5-11$. In order to get information on the functional ionizable residues involved in the active site of the transpeptidase. $\mathrm{pH}$ dependent kinetic experiments were carried out in the range of $\mathrm{pH} 6.0-10.0$ within which the enzyme activity is fully reversible. The kinetic parameters for the acceptor substrate. Gly-Gly at various $\mathrm{pH}$ were determined by Double reciprocal plotting and analyzed by the method of Dixon and Webb. ${ }^{18}$

Photooxidation. The photooxidation experiments were performed according to the method described by Rippa and Pontremoli with minor modifications. ${ }^{19}$ Methylene blue, at a final concentration of $0.001 \%$ was added to the enzyme solution $(0.05 \mathrm{mg} / \mathrm{mL})$ in a test tube. which was put into distilled water in a 2 liter beaker. The water was circulated at $37^{\circ} \mathrm{C}$ and the enzyme solution was continuously bubbled with stream of air. The light source was a 300 watt tungsten lamp positioned at $10 \mathrm{~cm}$ away from the surface of the test tube. Aliquots were taken at various time and assayed for the enzymatic activity under the standard condition. A control experiment was nun in the dark under identical conditions.

Chemical modification. DEPC was freshly diluted with anhydrous ethanol just before use. The concentration of DEPC was spectrophotometically detemined by the reaction with L-histidine using a molar extinction coefficient of $3200 \mathrm{M}^{-1} \mathrm{~cm}^{-1}$ at $240 \mathrm{~mm}$ for $N$-carbethoxyhistidine ${ }^{3(1)}$ To the encyme solution $(0.05 \mathrm{mg} / \mathrm{mL})$ was added the ethanolic solution of DEPC $(1.0 \mathrm{mM}-3.0 \mathrm{mM})$ and the mixture was incubated at $37^{\circ} \mathrm{C}$. The ethanol concentration did not exceed $5 \%$ by volume and was found to have no effect on the activity and stability' of enzy'me during incubation. At various time intervals during incubation. aliquots were taken and assayed for the residual enzyme activity:

\section{Results}

The kinetic studies on the transpeptidase at various pH. The $\mathrm{pH}$ profile on the transpeptidase activity revealed a bell shaped curve with an optimum $\mathrm{pH}$ of 8.0 . (not shown). The result showed that the enzy'me activity was fully rever-

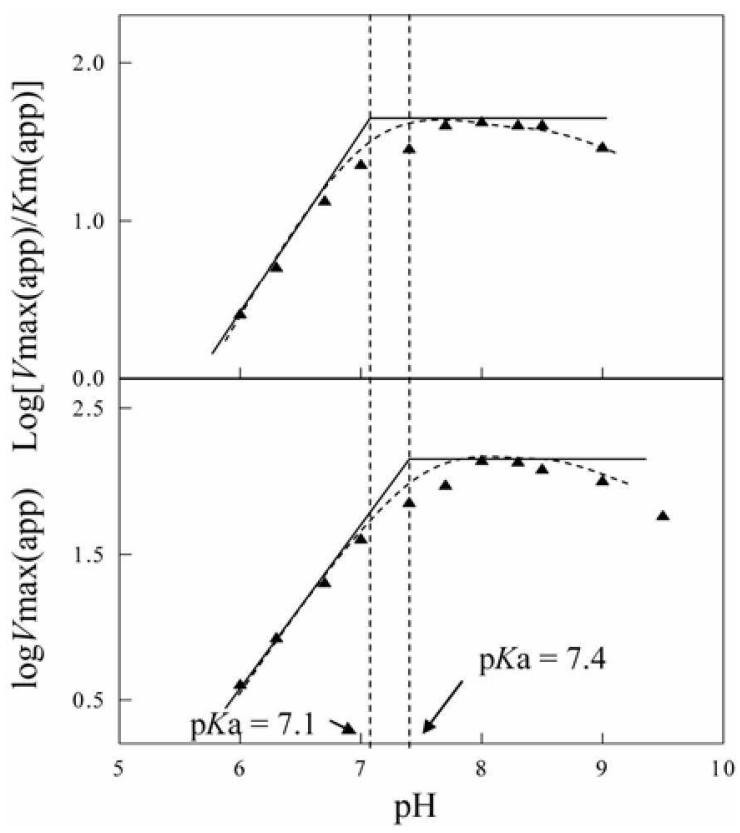

Figure 1. Effect of $\mathrm{pH}$ on the enzymatic activity of $\gamma$-GT tor GlyGly: The initial velocities were measured with the varying Gly-Gly concentration at the indicated $\mathrm{pH}$. The resulting kinetic parameters estimated by double-reciprocal plots were plotted by the method of Dixon and Webb.

sible in the range of $\mathrm{pH} 6.0$ to 10.0 and the enzyme was irreversibly denatured below $\mathrm{pH} 6.0$ or above $\mathrm{pH} 10.0$. which suggested that the activity variation in the $\mathrm{pH}$ range of 6.0 to 10.0 was due to the ionizable species affecting the enzymatic activity: In order to obtain information on the essential ionizable groups for the activity of the transpeptidase. a series of kinetic experiments in the range of $\mathrm{pH} 6.0$ to 10.0 were carried out with varying concentration of the acceptor substrate (Gly-Gly). The apparent $K \mathrm{~m}$ and $V \max$ values determined by Lineweaver-Burk plotting were analyzed according to the method of Dixon and Webb (Fig. 1) ${ }^{1{ }^{18}} \mathrm{~A}$ $\mathrm{pK}$ a value of 7.1 was estimated for an essential ionizable group of the free transpeptidase molecule from the plot of $\log (\mathrm{V} \mathrm{m} / \mathrm{Km})$ versus $\mathrm{pH}$ (upper panel in Fig. 1). The $\mathrm{p} K \mathrm{a}$ value of 7.4 obtained from the plot of $\log V / n$ versus $\mathrm{pH}$ (lower panel in Fig. 1) may be accounted for the ionizable residue of an enzyme-substrate complex. ${ }^{21}$ The $\mathrm{pKa}$ values determined by the Dixon and Webb's analysis are in the range of $\mathrm{pKa}$ value (5.9-7.5) for histidine residues found in biomolecules and comparable to the $\mathrm{p} K a$ values of 7.3 and 7.5 estimated for an essential histidine of neutral endopeptidase and thermolysin. respectively: ${ }^{21,23}$ The result of the $\mathrm{pH}$ dependent kinetic experiments, therefore. suggests that the rat kidney $\gamma$-GT contains at least one histidine imidazole group in the catalytic site.

The $\mathrm{pKa}$ values of an ionizable residue estimated by the Dixon and Webb's method using the $\mathrm{pH}$ dependent kinetic parameters for Gly-Gly were further confinmed by the same treatment with the kinetic parameters for the donor substrate ( $\gamma$-Glu-PNA) (not shown). The relatively high $\mathrm{pKa}$ value of 7.1 which is considered to be that of a histidine involved in 


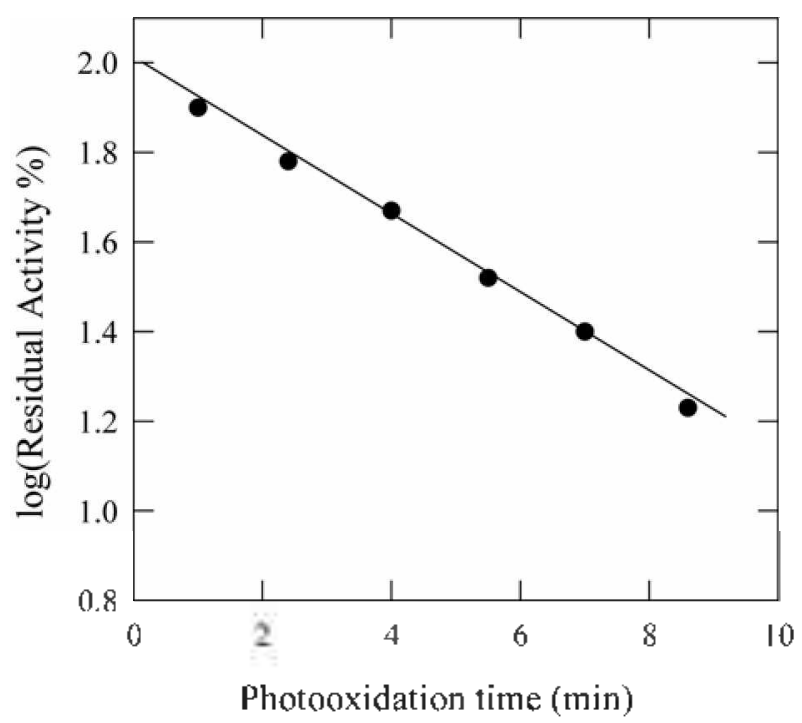

Figure 2. Kinetics of the inactivation of $\gamma$-GT by photooxidation in presence of methylene blue.

the enzymatic activity may be explained by the presence of negatively charged group(s) near the ionizable group. The higher $\mathrm{p} K \mathrm{a}$ value (7.4) of the histidine estimated from the plot of $\log \mathrm{lm}$ versus $\mathrm{pH}$ may suggest that the ionizable group is at or near the substrate binding site of the enzyme so that the positively charged imidazole group can be stabilized by the carboxylate of substrate

Photooxidation of $\gamma$-GT. The transpeptidase was irreversibly inactivated by photooxidation in the presence of methylene blue as shown in Figure 2. The loss of enzymatic activity follows first-order kinetics down to $80 \%$ inactivation. The enzy'me solution containing the dy'e did not lose the activity when kept in the dark as a control experiment. The $\mathrm{pH}$ effect of photoinactivation of $\gamma$-GT was carried out in the

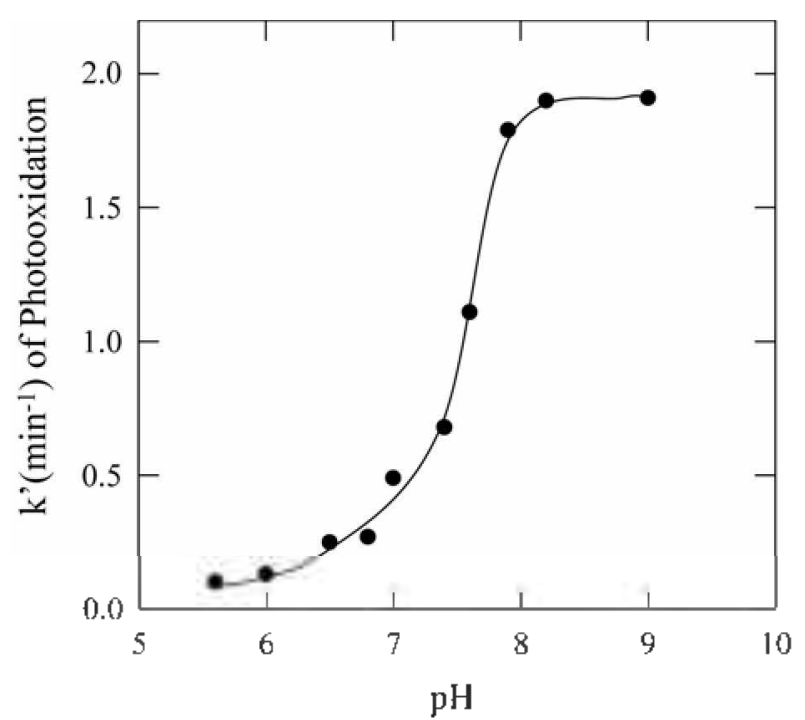

Figure 3. Effect of $\mathrm{pH}$ on the photoniactivation rate of the transpeptidase: Apparent tirst-order rate constants $\left(k^{\prime}\right)$ for the loss of enzymatic activity were estimated graphically from semilogarithunic plots sinilar to rig. 2

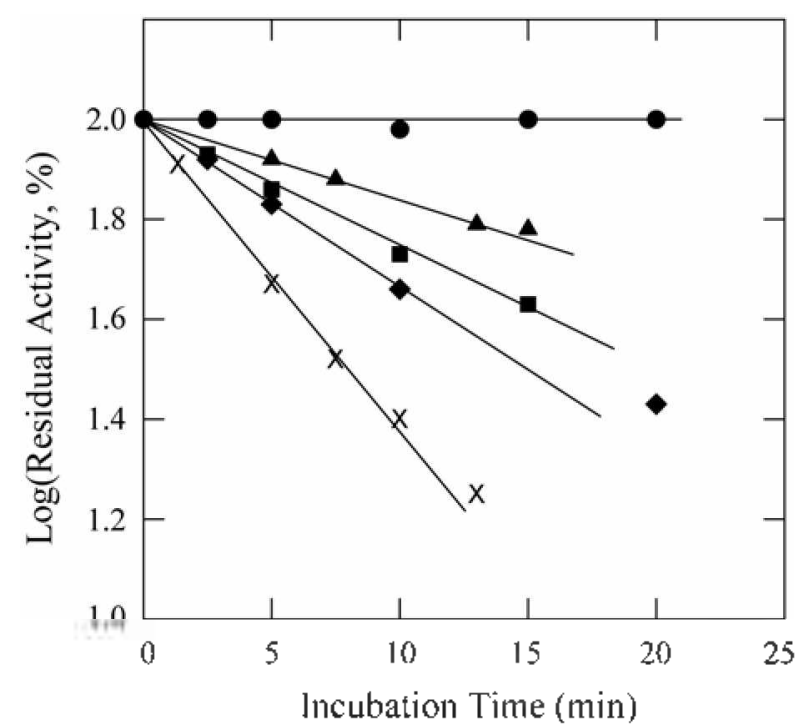

Figure 4. Inactivation of $\gamma$-GT by DEPC: The enzyme $(0.05 \mathrm{mg} /$ $\mathrm{mL}$ ) was incubated at concentrations of DEPC [control ( ) , $1.0(\bullet)$, $1.2(\square), 1.5(\bullet)$, and $2.4(\times) \mathrm{mM}$ ) in $50 \mathrm{mM}$ Tris-HCl (pH 7.0) at $37^{\circ} \mathrm{C} .10 \mathrm{~mL}$ of aliquot from the reaction mixture was taken at the indicated time intervals during incubation and the remaining activity was measured under the standard condition in a final volume of 1 $\mathrm{mL}$.

$\mathrm{pH}$ range of 6.0 to 9.0 . The dependence of the inactivation rate on the $\mathrm{pH}$ of the reaction mixture in Figure 3 showed a pattem similar to that obtained in the cases of the photooxidation of free histidine $e^{19,24}$ and of the photoinactivation of several enzymes in which histidine residues appeared to be involved in the mechanism of enzymatic reaction. ${ }^{25,26}$ The photoinactivation rate of $\gamma$-GT was significantly decreased at high ionic strength (not shown). The effect of the ionic strength excludes the possibility of methionine residues as direct participants in the photoinactivation process. The observations from the photoinduced inactivation indicate that histidine residue(s) could be essential for the maintenance of the protein confomation necessary for the catalytic activity or could directly participate in the enzymatic reaction.

Chemical modification by DEPC. Figure 4 shows the DEPC-concentration dependent inactivation of rat kidney $\gamma$ GT. The semilogaritlmic plot of remaining enzyme activity versus reaction time at various concentrations of DEPC showed a series of straight lines up to first $10 \mathrm{~min}$ of incubation. Prolonged incubation beyond $10 \mathrm{~min}$ resulted in a deviation from the straight line which is probably due to the significant rate of DEPC hydrolysis under the applied condition. The reaction order with respect to DEPC for the inactivation of the transpeptidase was estimated based on the fact that the apparent first order rate constant $\left(k_{\mathrm{app}}\right)$ depends on the concentration of DEPC as previously described by Levy et al. ${ }^{27}$ :

$$
\begin{aligned}
& k_{\text {anp }}=\mathrm{k}[\mathrm{DEPC}]^{n} \\
& \log \left(k_{\mathrm{a}, \mathrm{m}, \mathrm{n}}\right)=\log k+n \log [\mathrm{DEPC}]
\end{aligned}
$$

Where $k$ is the second-order rate and $n$ is the reaction order 


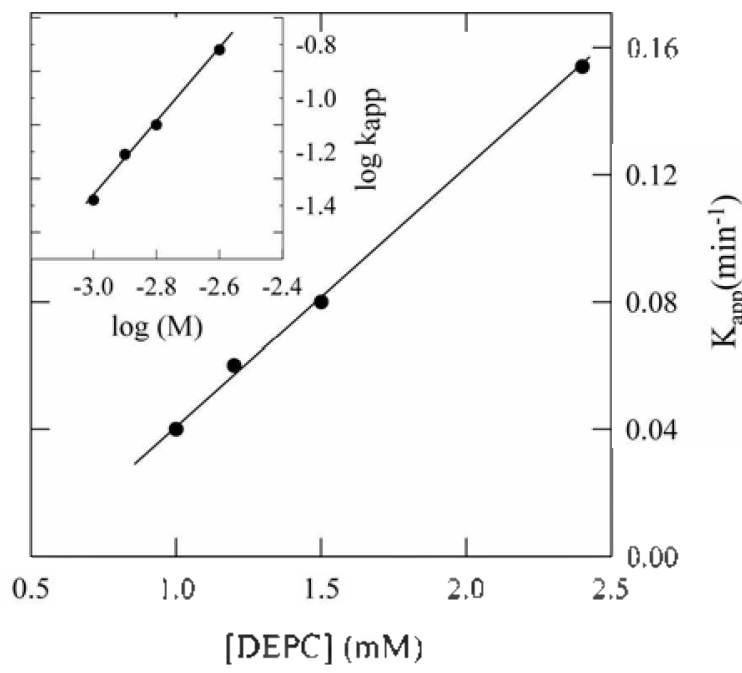

Figure 5. Plot of pseudo tirst-order rate constant $\left(k_{\text {app }}\right)$ against DEPC concentrations: Inset is the plot of $\log \left(k_{\mathrm{app}}\right)$ versus $\log [\mathrm{DEPC}]$. The pseudo first order rate constants of DEPC inactivation were calculated from the semilogarithmic plot (tig. 4) of residual activity versus incubation time at various tixed concentration of DEPC

of DEPC. The plot of $\log k_{\text {atpe }}$ versus $\log [\mathrm{DEPC}$ (inset in Fig. 5) gave a straight line with a slope of 1.3. indicating that a reaction of a single residue of the enzyme with one molecule of DEPC could be responsible for the total inactivation of enz'me. DEPC has been successfully used for the chemical modification of histidine(s) essential for the cataly tic activity in a number of enzymes. ${ }^{2 * 31}$ The pseudo first-order kinetics of the DEPC inactivation together with the first-order kinetics with respect to DEPC. therefore. suggests that the transpeptidase has a histidine residue that is essential for the enzymatic activity and accessible to DEPC.

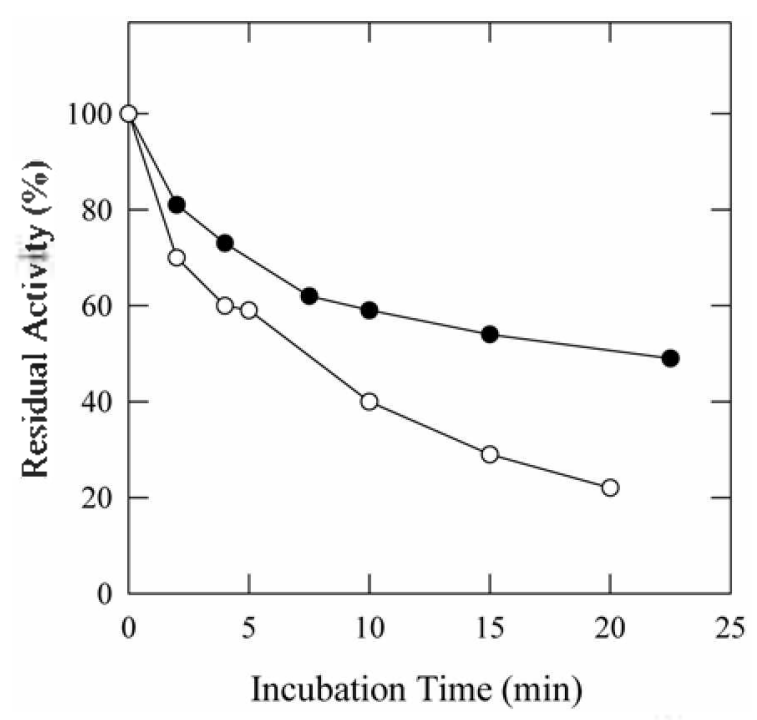

Figure 6. Effect of the substrate Gly-Gly on the chemical modification of $\gamma$-GT by DEPC: The enzyme was preincubated in presence $(\bullet)$ or absence $(\because)$ of $14.4 \mathrm{mM} \mathrm{Glv-Gly}$ in $50 \mathrm{mM}$ Tris$\mathrm{HCl}(\mathrm{pH} 7.0)$ before the addition of $\mathrm{DEPC}$ at a firial concentration of $2 \mathrm{mM}$.

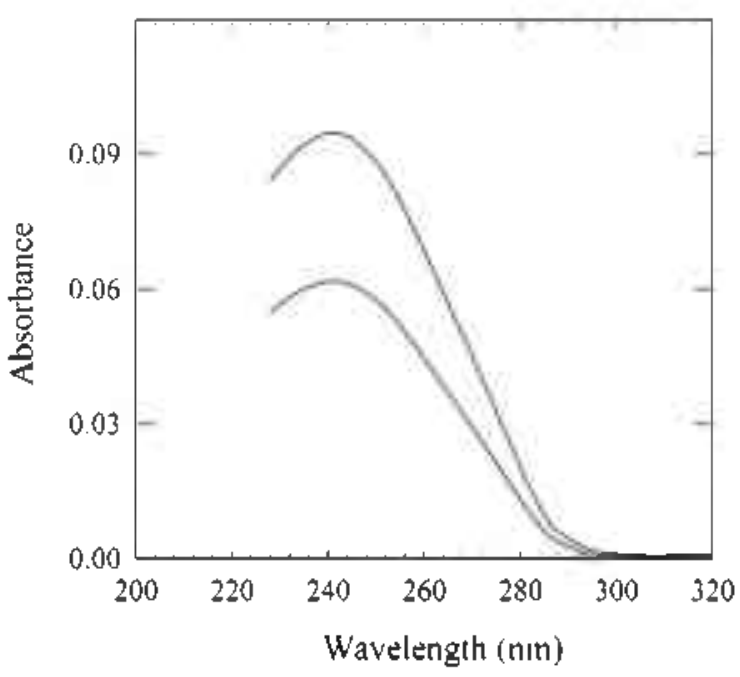

Figure 7. Difference spectra between DEPC-treated and -untreated enzymes: The sample contained $0.2 \mathrm{~mL}$ of the enzyme $(0.05 \mathrm{mg} /$ $\mathrm{mL}$ ) and $1.2 \mathrm{mM} \mathrm{DEPC}$ in $50 \mathrm{mM}$ Tris-HCl, pH 7.0. The apparent increase in absorbance at $240 \mathrm{~nm}$ was recorded after 5 and $10 \mathrm{~min}$ of incubation at $37^{\circ} \mathrm{C}$.

The effect of substrate on DEPC inactivation of the enzyme was examined by preincubating the substrate. Gly-Gly. and the enzyme before the addition of DEPC (Fig. 6). The enzyme was apparently protected from DEPC inactivation by the substrate. The substrate effect along with the firstorder kinetics of the DEPC modification indicates that the inactivation of enzyme by DEPC is due to the modification of a histidine group in the cataly tic site of $\gamma$-GT.

Although DEPC has a ligh reactivity toward histidine residue at neutral $\mathrm{pH}$. other nucleophilic groups such as tyrosine. serine. lysine. and cysteine might also be modified with this reagent probably at different $\mathrm{pHs} .{ }^{31,21}$ The difference spectra (Fig. 7) between enzyme alone and DEPCmodified enzyme gave an apparent increase at $240 \mathrm{~nm}$. indicating the formation of $N$-carbethoxyhistidine ${ }^{3 i}$ The reaction of the enzyme with $\mathrm{DEPC}$ does not result in decrease in the absorbance at $280 \mathrm{~nm}$ which could be accounted for the fomation of O-carbethoxyty rosine. 32

\section{Discussion}

The results of $\mathrm{pH}$ dependent kinetic experiments. photooxidation. and DEPC inactivation of the rat kidney $\gamma$-GT cooperatively support the claim that a histidine residue is essential for the enzymatic activity and involved at or near the binding site of acceptor substrate. Since the histidine is in mostly deprotonated state at the optimum $\mathrm{pH}$ of enzyme. it is hardly reasonable that Gly-Gly with free carbosylate anion binds to the uncharged imidazole group. The histidine residue, then. would function as a general base catalyst.

Five histidines are found in the light subunit of the rat $\gamma$ GT. Two of them are located at the positions of 382 and 504 in its precursor and other three are successively located at the C-tenninal region. ${ }^{33}$ As an attempt to identify the essential histidine of $\gamma$-GT, the ammo acid sequences of $\gamma$-GTs 


\begin{tabular}{|c|c|}
\hline E. $\operatorname{coti}(\mathrm{K} 12\}$ & \\
\hline PS. sp. (A14] & \\
\hline B. subtilis & \\
\hline HUMAN placenta & \\
\hline PIG brain & \\
\hline MOUSE kidney & \\
\hline RAT kidney & \\
\hline s. cerevisiae & \\
\hline E. $\operatorname{coti}(\mathrm{K} 12)$ & \\
\hline PS. sp. (A14) & \\
\hline B. subtilis & \\
\hline HURAN placenta & \\
\hline PIG brain & \\
\hline MOUSE kidney & \\
\hline RAT kidriey & \\
\hline S. cerevisiae & \\
\hline E. $\operatorname{coti}(\mathrm{K} 12)$ & \\
\hline PS. Sp. (A14] & \\
\hline B. Subtilis & \\
\hline HUMAN placenta & \\
\hline PIG brain & \\
\hline MOUSE kidney & \\
\hline RAT kidney & \\
\hline S. cerevisiat & \\
\hline
\end{tabular}

\section{$\frac{1}{7} *$}

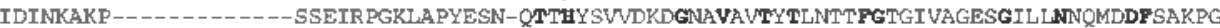
THPOKAGI - .......... SOETKPG-VPPHEGS - NTHTHYSIVDKDGNAYSVTYTLNDWFGAKUMANGTGVL NDEMDDFTSKVG INLDQVNKKPKAGDFWKYOEGSANYKQVEQPKDKVEGOTIRFTVADRWGNVVSTTTI EOLFGTGIMV PDYGVI LNNELTDFDA I PISDDTTHP-- - - - - ---ISYYK PEFYTPDDGG- -TAHLSVVAEDGSAVSATSTINLY FGSKVRS PVSGI FNNEMDDFSSPS ISDTTTHP----------D DYYEPEFYTPDDAG--TAHL SVVSDDGSAVSATSTINLYFGSKVRSRISGILFNDEMDDF SSPNITDETTHP-- - - - - - AAYYE PEFYLODDGG- - TAHLSAVSEDGSAVAATSTINL YFGSKVLSRVSGI FNDEMDDF SS PN -

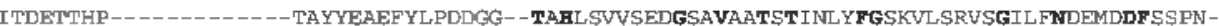
IKRNSQDGNFKTLEN------WTLYDPAYDINNPHG - TABFSIVDSHGNAVSITTTINLLFGSLVHDPKTGVI FNNEMDDFAOFN-

VPNWYGLVGDANAVGPNKRPISSMSPTIVYK-DGKTWLVTGSPGGSRIITTVLOMNNSTDYGINVAEATNAPRFHHOLLPDELRV

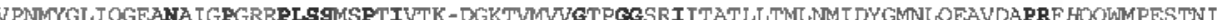
- .-- -GGANEVOPNKPPLSSMTPTILFK -DDKPVLTVGSPGOATIISSVLQTILYHIEYGMELKAAVEEPRIYTNSMSSYRYE ITNEFGVP PPANE IQPGKOPLSGMCPTIMVGODGOVRUVVAAAGTOITTATALAI I YNLWF GYDVKRAVEEPRLHNQLLPNVTTV ITNOFGVRPSPANF ITPGKOPLS\$MCPVI IVGELGQVRMVUGA SGGTOITT \$TALAI IHSLWFGYDVKRAVEEPRLHNOLLPNTTTL

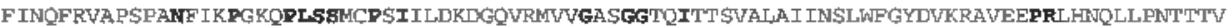
FTNOFGUAPSPANF I KPGKOPLSSMCDSIIVDKDGKURMVYGA SGGTOITTSVALA I INSLWFGYDUKRAVEEPRLHNOLLPNTTTY

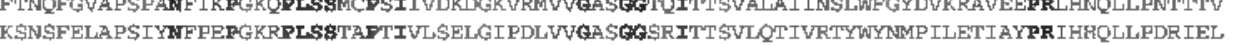

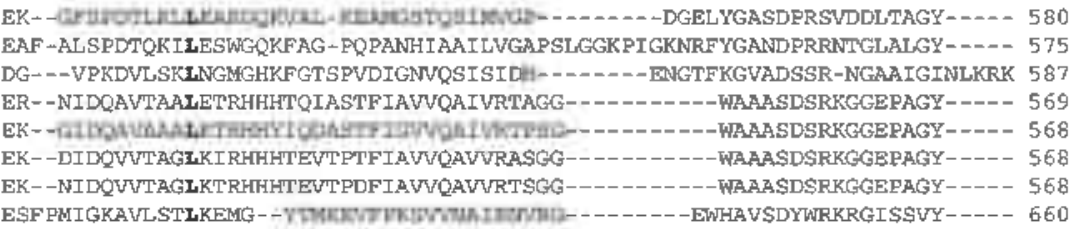

Figure 8. The amino acid sequence comparison of $\gamma$-GT precursors trom various organisms: The N-teminal residue of the L subunit is indicated by $\downarrow$. The highly conserved residnes are shown in bold. The histidines equivalent to His382 and His504 of the rat $\gamma$-GT are marked by an asterisk $(*)$. The sequences of the enzymes were collected from the SWISS-PROT data bank. The abbreviations used are: $E$., Escherichai, Ps, Psezdonomas; B, Bacillas, S, Saccharomeces.

from various organisms were collected from the SWISSPROT data bank and aligned using PileUp program (default setting) of the Genetics Computer Group's (GCG) sequence analysis software package. Figure 8 shows the amino acid sequence aligmment of $\gamma$-GTs from various species. It appears that His 382 is completely conserved among the enzymes. suggesting that His382 may be the general base catalyst. It is also noteworthy that His504 is conserved in the enzymes of mammalian species. The present work provides a valuable data for further study such as site directed mutations and Xray crystallography to understand the active site nature as well as the detailed catalytic mechanism of $\gamma$-GT.

Acknow ledgements. We thank Mr. Keon-Ho Han and Mr. Min-Woo Choi for teclnical assistance and Dr. Kyoungho Suk for helpfil discussions and kind review of the manuscript before submission.

\section{References}

1. Meister, A.: Tate, S. S: Griffith, O. W. Methods Enzzmol. 1981. 77.237.

2. Sacchetti. L.: Castaldo. G.: Cimino. L.: Budillon. G.: Salvatore. F. Chin. Chim Acta 1988. 177, 167

3. Bulle. F.: Mavier. P.: Zatrani. E. S.: Preaux. A.-M.: Leses. M.-C.: Siegrist. S.: Dhumeaux. D.: Guellaen. G. Hepatologv 1990. H. 545.

4. Antoine, B.: Visvikis, A; Thioudellet C: Rahimi-Pour, A.: Strazielle N. Wellnan, M. Siest G Biochem. J. 1989, 262.535.

5. Arai, K: Yoshida K.-I: Komoda. T.: Kobayashi, N.: Sakagishi. Y. Clin Chim Acta 1992. 210.35

6. Roth. J. Biochim. Biophys Acta 1987.906.405

7. Arai. K.: Sumi. S.-H.: Yoshida. K.: Komoda. T. Biochim. Biophws. Acta 1995. 1253, 33 .

8. Meister A.: Tate, S. S. Amm Rev. Biochem. 1976, 45, 559

9. Hughey. R. P.: Coyle, P. J: Curthoys, N. P. J. Biol Chem. 1979.
254. 1124

10. Tsuji, A.; Matsuda. Y: Katunuma. N. J. Biochem. Tohyol 1980. 87. 1567.

11. Sakamuro. D: Yanazce. M:: Matsuda. Y: Kangawa. K:: Taniguchi. N.: Matsuo. H.: Yoshikawa. H: Ogasawara. N. Gene 1988. 73. 1.

12. Nash. B.: Tate. S. S. J. Biol. Chem. 1982. 257. 585.

13. Rajagopalan. S: Park. J.H.: Patel, P. D; Lebovitz. R. M.: Lieberman. M. W. J. Biol. Chem. 1990, 265, 1172.

14. Castonguay, R.: Lherbet, C.: Keillor, J. W. Bioorg. Med Chem 2002. 10. 4185 .

15. Hughey. R. P.: Curthoys. N. P. J. Biol. Chem. 1976. 251.7863.

16. Tate, S. S.; Meister. A. J. Biol. Chem 1974. 249.7593.

17. Lowry, O. H. Rosebrough. N. J.: Farr, A. L.: Randall, R. J. d. Biol. Chem. 1951. 193. 265.

18. Dixon. M.: Webb. E. C. The Enzmmes. 2nd ed.: Longmans Green London. 1964: $p 108$.

19. Rippa. M.: Pontremoli. S. Biochemismy 1968. 7.514.

20. Miles. E. W. Hethods Enzumol 1977. 47.431

21. Cleland. W. W. Methods Enzymol. 1982, 87,390.

22. Robert, C. B; Louis, B. H. Biochemistry 1987. 26. 4237.

23. Pangburn. M. K.: Walsh, K. A. Biochemistry 1975. 14, 4050.

24. Weil. L. Arch Biochent Biop/ns 1965. 110.57.

25. Martinez-Carrion. M.: Turano. C.: Riva. F.: Fasella. P. J. Biol. Chent $1967.2+2.1426$

26. Chatteriee, G. C. Noltmann, E. A. E. J. Biochem 1967. 29

27. Levy. H. M: Leber, P. D.: Rvan, E. M. J. Biol. Chem. 1963, 238. 3654.

28. Ghazaleth. F. A.: Omburo. G. A.: Colman. R. W. Biochemical J 1996. 317. 495

29. Paudel. H. K.: Yu. L.: Yu. C.-A. Biochim. Bioplns. Acta 1991. 1056,159

30. Tian. W. X.: Hsu. R. Y.: Wang. Y. S. J. Biol Chem. 1985. 260. 11375 .

31. Muhlrad. H.: Hegy. G.: Horany. M. Biochim. Biophns dicta 1969. 181. 184.

32. Melchior. W. B.: Fahrney. D. Biochemism 1970. 9.251

33. Laperche. $Y ;$ Bulle. F.; Aissani, T.: Chobert. M. N ; Aggerbeck. M:- Hanoune, J: Guellaen, G. Proc. Natl Acad Sci. USA 1986. 83.937. 